\title{
Triadic value propositions: When it takes more than two for tango
}

\author{
Christian Kowalkowski, Daniel Kindström and Per Carlborg \\ Journal Article
}

\section{Tweet}

N.B.: When citing this work, cite the original article.

Original Publication:

Christian Kowalkowski, Daniel Kindström and Per Carlborg, Triadic value propositions: When it takes more than two for tango, Service Science, 2016. 8(3), pp.282-299.

http://dx.doi.org/10.1287/serv.2016.0145

Copyright: Informs Pubs OnLine

http://pubsonline.informs.org/

Postprint available at: Linköping University Electronic Press

http://urn.kb.se/resolve?urn=urn:nbn:se:liu:diva-117961

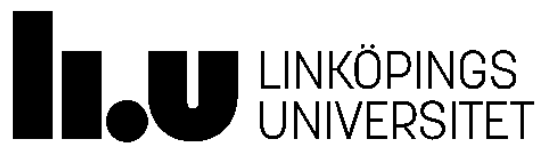




\title{
TRIADIC VALUE PROPOSITIONS: WHEN IT TAKES MORE THAN TWO TO TANGO
}

\author{
Christian Kowalkowski ${ }^{a, b^{*}}$ \\ Daniel Kindström ${ }^{a}$ \\ Per Carlborg ${ }^{a}$
}

\begin{abstract}
${ }^{a}$ Department of Management and Engineering, Linköping University, SE-581 83 Linköping, Sweden

${ }^{\mathrm{b}}$ Department of Marketing, CERS - Centre for Relationship Marketing and Service Management, Hanken School of Economics, PO Box 479, FIN-00101 Helsinki, Finland
\end{abstract}

* Corresponding author. tel: +46 13281571

E-mail addresses: christian.kowalkowski@hanken.fi (C. Kowalkowski), daniel.kindstrom@liu.se (D. Kindström), per.carlborg@liu.se (P. Carlborg).

This is a so-called personal version (author's manuscript as accepted for publishing after the review process but prior to final layout and copy editing) of the article.

Original article:

Kowalkowski, C., Kindström, D., \& Carlborg, P. (2016), Triadic value propositions: When it takes more than two to tango, Service Science, Vol. 8, Issue 3, pp. 282-299.

http://dx.doi.org/10.1287/serv.2016.0145

Copyright: INFORMS www.informs.org

Readers are kindly asked to use the official publication in references. 


\begin{abstract}
Value propositions are reciprocal resource-integration promises and value alignment mechanisms, operating to and from actors seeking an equitable exchange. In a business triad, any change in the relationship between two actors also affects relationships with the third actor, influencing resource integration and value creation at the value constellation level. This study of the development of a triadic value proposition analyzes how the discontinuous effects of a new service initiative alter the relationships among actors in a manufacturerdealer-user triad. A qualitative empirical inquiry examines a ten-year process, in which a leading industry incumbent enters the service business by crafting a triadic value proposition. As the value proposition evolves over time, the network ties - and thus the interdependence among manufacturer, dealer, and user — strengthen. The findings offer firms a better understanding of how to involve and collaborate with key actors to initiate discontinuous changes at the firm and network levels. These insights are particularly timely in light of the difficulties that product firms face when intermediaries are decisive for the success of their service-led growth initiatives.
\end{abstract}

Keywords: value proposition; network ties; relationship development; service systems; case study application

\title{
Application abstract
}

Developing a value proposition is a critical strategic issue for marketing managers. Even as competitive advantage increasingly appears in networked business models though, the concept of the value proposition has yet to be extended to multilateral settings. For example, studies of service-led growth in industrial contexts often focus on the manufacturer and customer but omit service partners as critical actors. The authors therefore suggest a triadic value proposition and analyze how such value propositions might evolve over time in an industrial context, a setting in which service partners' performance often is a foundation for manufacturer success. Substantial adjustments to the arrangement between two parties likely influence what can be proposed to the third, which makes collaboration with all parties necessary to initiate any discontinuous change at the network level. To make this concept more actionable, the authors also illustrate how managers might approach the task of crafting triadic value propositions. The insight for management is straightforward: By adopting a triadic perspective while developing the value proposition, companies can increase the viability of their service system and provide a more compelling market offering. 


\section{Introduction}

The concept of "value propositions" appears increasingly in both academia and practice, such that developing the value proposition constitutes a critical strategic issue for senior marketing managers (Payne and Frow 2014b). From a marketing strategy perspective, Webster (2002) argues that the value proposition “should be the firm's single most important organizing principle" (p. 61). Along with the idea of a "service system," it is a foundational concept for the emerging field of service science (IfM and IBM 2008). Yet existing concepts and views of value propositions may be inadequate for understanding how companies can gain competitive advantages and achieve differentiation in service systems comprising more than two actors. With a few important exceptions (Ballantyne et al. 2011; Frow and Payne 2011; Frow et al. 2014), the buyer-supplier dyad remains the focus of research into value propositions. More recent conceptualizations highlight interdependence and reciprocity as critical elements, yet even these concepts remain primarily dyadic (e.g., Ballantyne and Varey 2006; Kowalkowski 2011; Payne and Frow 2014a).

A dyadic perspective may be too limited to comprehend contemporary value cocreation phenomena though, especially those that take place in service systems (Basole and Karla 2014; Karmarkar and Roels 2015; Lempinen and Rajala 2014; Rajala et al. 2015). As Storbacka and Nenonen (2011) point out, "firms are increasingly engaged in complex market configurations where the alignment of market views becomes central for success. Firms therefore need to offer ... their view on how the market should be configured, and engage actors in activities aimed at creating a shared market view" (p. 264). In practice, even service systems with only three firms (e.g., manufacturer, dealer, and user) can prove highly complex as market configurations.

Triads of independent firms that connect through network ties, either directly or indirectly, for the purpose of doing business represent complex market configurations. Their 
network ties can be structural, economic, or social in character (Håkansson and Snehota 1995). A case in point is the Illinois-based company Caterpillar, a global leader in earthmoving products. To realize its value propositions, the company needs to foster network ties with users of its equipment but also with dealers that sell and service that equipment. Caterpillar operates through an extensive network of independent dealers in over 180 countries and refers to those dealers as "a critical competitive differentiator" and "the foundation" of its worldwide success. However, Caterpillar also believes its dealers may be missing out on US\$9-18 billion annually in easy-to-capture revenue, such that they need to enhance their service operations to boost their share of the global service market. Despite the integration of diagnostic technologies into Caterpillar machines, dealers have not capitalized on these assets sufficiently to grow their service business. As the Group President in charge of dealer relations acknowledged, neither has the company sufficiently "directed them to do it or helped them to do it" (Kelleher 2014). In addition to such anecdotal evidence, prior research suggests the need to move beyond buyer-supplier dyads when analyzing service-led growth in industrial contexts (Kowalkowski et al. 2013; Nordin et al. 2013). In particular, triadic analysis likely is vital for understanding other prominent network structures, such as competitor alliance networks (Madhavan et al. 2004; Wu et al. 2010) or service triads (Wynstra et al. 2015).

In response to calls to extend the concept of a value proposition to multiple stakeholders (multilateral value propositions; Kowalkowski 2011) and for detailed investigations of how context-specific value propositions develop and evolve over time in service systems (Frow and Payne 2011; Frow et al. 2014), we consider the development of a triadic value proposition and analyze how the discontinuous effects of a new-to-the-industry service initiative might change relationships among actors in the business triad. This research is based on a ten-year case study of an incumbent multinational firm's process of entering the 
service business, such that it significantly altered the value proposition and the relationships among the three actors - manufacturer, dealer, and user-in the system.

In turn, this study makes several contributions to theory and practice. First, we conceptualize a triadic value proposition that embeds dyads. In light of the increasing number of business models that build on business triads, it is timely to investigate this triadic value proposition. Second, with a qualitative empirical inquiry, we analyze how a successful value proposition evolves over time in a networked setting and thereby capture the interactive character of a network, which a dyadic study could not capture. Third, we delineate the network ties required for service provision in business triads. Fourth, to ensure the actionability of this concept, we illustrate how organizational practitioners might approach the task of crafting triadic value propositions.

\section{Theoretical background}

As a theoretical foundation, we outline the evolution of the value proposition concept and its manifestation as a triadic value proposition. We also briefly review research on network ties in business triads and present two archetypes.

\subsection{Value proposition: From firm-centric to service-dominant perspectives}

A value proposition is a reciprocal promise of value, connecting actors within a service system. However, early conceptualizations characterized value propositions as initial steps in the supplier firm's value delivery process (cf. Ballantyne et al. 2011), resonant with a mechanistic manufacturing logic rather than a service logic (Kingman-Brundage et al. 1995; Normann 2001; Ramírez 1999). Although they adopted what they called a customer-oriented perspective, early works on value propositions emphasized the "delivery of value" by a supplier, such that the value proposition constitutes an implicit promise to customers to deliver some particular combination of values (Anderson et al. 2006; Treacy and Wiersma 1995). Many studies continue to regard value propositions through a somewhat mechanistic 
lens, emphasizing the supplier-crafted value for customers, manifested as deliverable value offerings, and generally equating the concept with a market offering (e.g., Anderson et al. 2007; Covin et al. 2015; Levina and Ross 2003; Martos-Partal et al. 2015). A small but growing number of studies focus on the reciprocal nature of value propositions though, moving from a supplier-dominant to an initiator-participant perspective, generally according to the service-dominant logic (SDL) (see Appendix 1).

In particular, Ballantyne and Varey (2006) advance the value proposition concept and align it with the SDL. They agree with Vargo and Lusch (2004) regarding the provisional state of value propositions, such that value-in-use is the enactment of value propositions that buyers and sellers express. Both customer-related factors and supplier-internal capabilities therefore influence the type of value proposition that is suitable for different usage contexts. For example, a potential buyer's financial policies affect the value proposition, because they define the scope of the offering that the buyer can purchase. Therefore, the relative emphasis on value-in-use and value-in-exchange differs across value propositions. Furthermore, any involved actor can initiate reciprocal value propositions (Kowalkowski 2011).

As Grönroos and Gummerus (2014) observe though, SDL literature often is implicitly firm-centric, such that the provider appears to drive value creation because it seeks to create value propositions (Lusch and Webster 2011; Payne et al. 2008; Vargo and Lusch 2004). As Ballantyne et al. (2011, p. 205) point out, the original SDL view (e.g., Vargo and Lusch 2004) did not emphasize the reciprocal nature of value propositions; there is no evident reciprocity or flexibility if the provider simply puts forward a proposal. Furthermore, SDL literature has not addressed the crafting or adoption of value propositions in practice (Frow and Payne 2011). Overall though, SDL has been an influential perspective for advancing marketing theory on value propositions, similar to value propositions from a service (eco)system perspective (e.g., Chandler and Lusch 2015; Frow et al. 2014) and the practices 
of forming value propositions (Kowalkowski et al. 2012; Skålén et al. 2014). As Truong et al. (2012) have noted, there also are considerable commonalities between the SDL framework and more established observations from the Industrial Marketing and Purchasing (IMP) Group regarding interactions of organizations. From the IMP perspective, interdependent actors influence and adapt to one another's resources and activities, which characterizes interactions (Ford et al. 1986). Reciprocal communication thus is central to IMP thinking; value is inherently reciprocal and unique to each participant in an interaction (Ford 2011).

Beyond the dyad, and building on previous SDL conceptualizations (e.g., Ballantyne and Varey 2006), we define a triadic value proposition as a reciprocal resource-integration promise and value alignment mechanism, operating to and from three actors that seek equitable exchanges. The value proposition connects actors within the service system (IfM and IBM 2008; Maglio and Spohrer 2008; Vargo and Akaka 2009). In a commercial context, it should identify idiosyncratic benefits and sacrifices for all actors, as well as how value can be realized through activities and resources. Actors perceive a superior value proposition as more viable than other potential value propositions or the status quo. If accepted, a value proposition gets materialized as a market offering, through which actors engage in value fulfillment processes (Grönroos 2008; Kowalkowski 2011). If the elements (benefits or sacrifices) of the resource-integration promise between two actors change, it should affect relationships with the third actor, with an influence on resource integration and value creation at the overarching, value constellation level. As a resource-integration promise, the value proposition also is an invitation to engage in service through future market offerings (Chandler and Lusch 2015). The idiosyncratic and contextual value perceptions of all decision makers mean that the value proposition is uniquely accessed and evaluated by each actor. To achieve congruence among actors' interests, the value proposition must be crafted 
interactively to accommodate value alignments in future equitable exchanges; otherwise, the subsequent market offering is likely unsustainable (Kowalkowski 2011).

\subsection{Network ties in business triads}

Business relationships are interconnected; changes in one relationship always affect the others, to varying degrees (Håkansson and Ford 2002). In such systems, beyond dyadic customer-provider relationships, it is important to consider triads and more extensive networks. For example, service networks can be characterized as a "loosely coupled collection of upstream suppliers, downstream channels to market and ancillary service providers" (Gebauer et al. 2013, p. 32). In business networks with distinct structures, relationships reflect intentionally created constellations of actors who pursue repeated and enduring exchange relations with one another and deliberately work together to mobilize value creation (Achrol 1997; Dyer and Nobeoka 2000). We conceptualize these structures as value constellations (Normann and Ramírez 1994) and adopt an actor-defined perspective, in which a focal actor strives to configure adjacent business relationships through networking activities (Corsaro et al. 2012; Kowalkowski et al. 2013). In value constellations, value creation is an outcome of interactions among actors (Ramírez 1999), and competitive advantage exists at the constellation rather than the firm level (Gomes-Casseres 1994; Möller and Svahn 2006).

Business triads as value constellations already have been studied from relationship marketing, interaction, and network perspectives (Havila et al. 2004; Holma 2010; Nätti et al. 2014; Ritter 2000; Salo et al. 2009). This body of research emphasizes the in-depth study of triads as an important step toward a deeper understanding of broader systems of actors. For example, Ritter (2000) discusses how influencing other relationships can change a focal relationship's performance. From an operations management perspective, Wynstra et al. (2015) note how altered value propositions require new relationships within the triad - for 
example, a manufacturer must ensure the dealer's ability to deliver services, consistent with the value proposition between the manufacturer and the user. A shift from dialogue to "trialogue" thus is essential for value propositions in a triadic setting (Nätti et al. 2014).

However, prior literature on business triads has not linked to research on value propositions, nor does value proposition literature generally look beyond the buyer-supplier dyad. The exceptions are Ballantyne et al.'s (2011) and Frow and Payne's (2011) conceptual studies, which consider value propositions and the co-creation of value across a broader range of stakeholders (e.g., customers, suppliers, alliances). Otherwise, scholars discuss value propositions only in relation to supplier-customer dyads, without empirical insights. Although Kowalkowski et al. (2012) study the formation of a value proposition involving three resource-integrating actors for example, they represent only two distinct parties: the retail firm and potential buyers. Payne and Frow (2014b) focus specifically on supplierdriven customer value propositions as "an encapsulation of a strategic management decision on what the company believes its customers value the most and what it is able to deliver that gives it competitive advantage" (p. 215). Similarly, Cova and Salle (2008) introduce the concept of a customer network value proposition, which reflects the idea of a network or constellation on the customer side, though it generally indicates a statement of benefits delivered by the supplier (and its supply network) to the customer (and its customer network). That is, despite its network perspective, it includes only two focal actors. Extending the discussion from a dyadic to a triadic level, where multiple actors influence and are influenced by value propositions, thus represents an important step toward a broader conceptualization.

Actors connect through various ties: structural and technical, economic and legal, and social and relational (Håkansson and Snehota 1995; Holmlund and Törnroos 1997). Their triads also might be transitive (Havila et al. 2004; Madhavan et al. 2004) or intransitive. In intransitive triads, which are common in fragmented market channels (e.g., Matthyssens and 
Vandenbempt 2008), actors A and C both have ties to B (the tertius) but no direct ties to each other (see Figure 1, Panel a) (Madhavan et al. 2004). To reduce the potential problems of a third-party barrier to its end customers though, a supplier might secure these links through network ties (Nordin et al. 2013), such that each of the three firms has direct ties with the other two, constituting a transitive triad (Figure 1, Panel b). A change from intransitive to transitive triads inherently influences the value propositions across the three actors.

\section{--INSERT FIGURE 1 HERE--}

In intransitive triads, because two of the actors have no direct ties, a triadic value proposition does not exist conceptually. In Figure 1, Panel a, dyadic value propositions arise between $\mathrm{A}$ and $\mathrm{B}$ and between $\mathrm{B}$ and $\mathrm{C}$, but no resource-integrating promise or value alignment mechanism operates to or from all three actors. A change in the value proposition between $\mathrm{A}$ and $\mathrm{B}$ should have no direct effect on the proposition between $\mathrm{B}$ and $\mathrm{C}$, and vice versa. For the value proposition to operate to and from all actors, they all must be connected through some ties. To establish a triadic value proposition with such interdependence, a transitive triad thus is required.

\section{Method}

This research seeks to contribute to and extend existing theory on value propositions in service systems by emphasizing business triads. To add to existing knowledge, we select an information-rich object of study (Dubois and Gadde 2002), so that we can analyze the network ties among all three actors in the value constellation. Methodologically, studying the development of a triadic value proposition as it emerges and develops in a real-life context offers benefits, in terms of data richness and greater understanding of how events originate and evolve over time. Case studies can enable researchers to acquire a "deep understanding of the actors, interactions, sentiments, and behaviors occurring for a specific process over time" (Woodside and Wilson 2003, p. 497). Pettigrew (1987) also suggests that applying a 
method that is both contextual and processual in nature can help overcome the inherent weaknesses of research that focuses on change over time.

As a starting point, this research begins with a global manufacturing firm's first major entry into a service market. This firm decided to enter the service market in one of its key business areas by developing and offering a new value proposition geared toward end users (henceforth, "users") of its more advanced products (approximate price range US $\$ 8,000$ 30,000). Traditionally the manufacturer had operated through a (primarily) independent, third-party dealer network (henceforth, "dealers"), with little or no contact with the end-users of its products. This change therefore redefined existing relationships within the network and value proposition characteristics; to succeed, the value proposition had to become triadic.

To depict this departure from the manufacturer's initial situation, we strived to incorporate the perspectives of all three actors in the particular value constellation. The triadic approach accounts for these corresponding perceptions, rather than focusing on one or two (see also Holmlund and Strandvik 1999). A single case study approach also is appropriate for understanding the concept of triadic value propositions, because this phenomenon is embedded in complex relationships, and the existing body of knowledge is insufficient (Halinen and Törnroos 2005; Normann 1970; Olkkonen and Tuominen 2008).

\subsection{Case selection and data collection}

The choice of case firm was a deliberate research decision, designed to increase external validity and ensure some degree of generalization (Gibbert et al. 2008; McDermott 1999), such that the findings should apply to other service systems in similar settings (i.e., service-led growth in industrial contexts). The selected case thus was chosen for theoretical rather than statistical reasons (Gummesson 2000). As Normann (1970, p. 73) notes, the possibilities to generalize from one single case are founded in the comprehensiveness of the measurements which makes it possible to reach a fundamental understanding of the structure, 
process and driving forces rather than a superficial establishment of correlation or causeeffect relationships. A further advantage of a single-setting, embedded case design is that it provides in-depth insights into the dynamic phenomena in interorganizational relationships (Yin 2003).

The data collection mainly relied on interviews with managers of the manufacturer and dealers, as well as users in multiple markets (see Table 1). The semi-structured interviews relied on three separate interview guides, one for each actor, that we derived from our theoretical background and that evolved as the research proceeded. The guides contained open questions about the actors' businesses in general, the equipment and its reliability, service strategies and value propositions, and relationships with other actors. We began with the manufacturer. In discussions with that actor, we identified key markets (i.e., those engaged in the launch of the new service contract: France, Poland, Sweden, the Netherlands, and the United States), along with relevant dealers and users, through snowball sampling (Coleman 1958). The initial manufacturer respondents also recommended particular dealers and users as respondents, due to their relevance to the specific service innovation project, as well as their experience and expertise. Therefore, we gained ready access to key respondents from all three focal actors. The authors conducted most of the interviews; some, mainly in France and the United States, were conducted by research assistants, using the provided interview guides. Most of the interviews also were recorded and transcribed, though a few respondents specifically asked not to be recorded, due to the confidential nature of the topics discussed. Two researchers participated in these interviews and took detailed notes.

\section{--INSERT TABLE 1 HERE--}

As Pettigrew (1990) emphasizes, "research is also a reciprocal activity," so in addition to the interviews, we conducted and participated in several internal manufacturer focus groups, as well as two larger workshops, involving multiple representatives from all three 
actors. The workshops and focus groups enabled further data collections and helped validate our understanding and preliminary analyses (Stewart and Shamdasani 2014). Secondary data, including the manufacturer's internal documents and dealer and customer documents, also provided input. Coupled with the participation of respondents from multiple levels and different roles, this form of data triangulation enhanced understanding even further (Gibbert et al. 2008; Yin 2003). We summarize the overall research process in Table 2.

\section{--INSERT TABLE 2 HERE--}

\subsection{Data analysis}

This study proceeded from the manufacturer's new service innovation concept, as well as the initial structural, technical, economic, legal, social, and relational ties among the actors in the service system. We analyzed the primary data to understand the emergence of the value proposition over time, how the network ties and multi-actor relationships evolved, and the nature of the final value proposition and associated ties. With the secondary data, we also sought to gain insights into the formalization of the service innovation concept and its associated structural, technical, economic, and legal ties. The analyses of the collected data followed what Dubois and Gadde (2002, p. 558) call a "systematic combining process." In practice, it meant that the conceptualization, empirical fieldwork, and case analysis evolved simultaneously.

The data were coded for content and summarized in case protocols (Yin 2003), analogous to Eisenhardt's (1989) concept of case write-ups and reflecting the theoretical background (e.g., types of network ties), so that we could detect value proposition-related patterns and themes. For example, to understand how the new service initiative affected the relationships among the actors in the manufacturer-dealer-user triad, we continuously analyzed what happened during each phase of the process (first sequentially and then from a more holistic perspective); the reasons that informed the decisions; and which reactions 
ensued among other actors in the triad. This process facilitated our in-depth exploration and analysis of the triadic value proposition (Kovács and Spens 2005), because we combined the analysis of the three dyads and their ties with the analysis of the whole triad. This approach for analyzing triads is supported by Choi and Wu (2009a, p. 270), who argue that "triads build on dyads, and any study on triads needs to build on studies on dyads."

\section{Findings}

We report on the emergence of the value proposition over time and how each of the three dyads in the triad changed.

\subsection{Empirical context and development of the value proposition}

This case study refers to a specific business development project initiated by a product manufacturer, extending over several years. Prior to the introduction of the triadic value proposition, the market situation was typical of many industries: The manufacturer used dealers as an indirect market channel to sell its products. The manufacturer thus had little interaction with users and only an indirect relationship with the end-user market. The multibrand dealers exhibited little loyalty to any specific brand, and very few of them offered any structured services to users. Competing manufacturers also were not offering any structured services in our case study context, so the focal manufacturer's offering was new to the industry and the market (cf. Garcia and Calantone 2002).

An important element of the case manufacturer's entry to the service business was its relatively weak position (i.e., low market share and little brand awareness) among customer segments using its advanced machines. Yet these particular segments also promised significant growth potential. As a product-centric firm, a strategically important driver of the manufacturer's initiative was an opportunity to stimulate future product sales through increased user awareness of the brand and increased penetration of its spare parts: 
Service is a great way to increase product sales and to increase our share of [the advanced machine market segment]. (Director of Services, Manufacturer)

Driving increased product sales can also alienate users though, so the manufacturer needed a wider approach to the concept of value propositions. As one user noted,

The manufacturer will sell more machines and the dealer more service, but it is me as a customer that will pay in the end. (Owner Manager, User firm)

Other key influences on the manufacturer's strategic decision to develop a value proposition based on services included the potential for an enhanced market position and strengthened relationships with both users and dealers, as well as increased total revenues.

Before the development of the triadic value proposition commenced, the actors (manufacturer, dealers, and users) had been embedded in an intransitive triad (Figure 1, Panel a). Accordingly, the existing value propositions were distinctly dyadic (i.e., manufacturerdealer and dealer-user), with no ties or interactions between the manufacturer and users and no overall triadic perspective. The dealer also undertook reactive maintenance and repair services only when machines broke down, so the manufacturer's ties to the user remained weak even after a purchase. Really, only the legal ties related to the product warranty connected them. In the absence of any direct ties to the user, the manufacturer's value proposition was directed toward dealers, and the dealer's value proposition for the user in turn focused primarily on new product sales (e.g., technical features) and the promise to provide input. Table 3 describes the network ties in this initial intransitive triad.

\section{--INSERT TABLE 3 HERE-}

\subsubsection{Initializing the value proposition.}

The idea of offering services and the related initial value proposition started to form in 2004, in what we define as Phase 1. It focused on idea generation and understanding the structure of the initial value proposition, such as user needs and the cost structure. Key issues 
in this phase included how (if at all) a future value proposition might be bundled, the user's likely willingness to pay for different service options, and how user needs differed across various markets. In attempting to understand user needs, the main activities involved the manufacturer-user dyad (e.g., usage patterns, business processes), which previously had not been emphasized.

\subsubsection{Developing the value proposition.}

As the idea of a new value proposition matured, the process moved into what we consider the main development phase, Phase 2, in which the key activities included more structured and detailed user studies and efforts to understand the dealer's role, along with initial pilot tests of the value proposition. On the basis of user input and the simultaneous development of the technology to enable the service provision (e.g., sensor technologies, web applications), the value proposition transformed from its early concept into something resembling the future final value proposition:

We managed to develop really interesting features. This would not have happened with a traditional development process, and we needed customer interaction and an open process starting with the customers' real needs. (Director of Services, Manufacturer)

Also in this phase, the technological development opened new opportunities to capture and analyze product usage data, as well as individual operator (user-based) data, which influenced the further development of the value proposition. The initial focus on the manufacturer-user dyad extended to the manufacturer-dealer dyad, as well as tentatively addressing the dealer-user dyad (from the manufacturer's point of view), such that it started to approach a triadic perspective. 
A key challenge at this point was the dealers' inability to recognize the potential benefits of the proposed value proposition, which they believed would mean new efforts without any direct positive effect on their business. As one dealer stated,

[What] the customer pays goes to the manufacturer, and not a single percent to us.

Where in this are we going to earn money? I doubt whether this new service will give me increased service sales income through preventive maintenance. (Owner Manager, Dealer)

Workshops with participants from all three actors (manufacturer, dealers, and users in different markets) increased understanding of each party's needs though, and this information served to develop the value proposition further. As a manufacturer representative explained: The aim of the workshops is to understand how we should develop our new services to best fulfill the needs of our customers and dealers. We want to find a methodology to work with these issues. (Director of Services, Manufacturer)

\subsubsection{Launching the value proposition.}

In Phase 3, the value proposition materialized as a market offering and launched on multiple markets, with a select number of dealers and users in each market. This approach ensured increased control over the actual launch process and provided access to qualified feedback from actors who were willing to commit to this new value proposition in reality. A key activity was to build support and understanding for the value proposition among all three actors and to understand what was needed to realize the full potential of the value proposition during the subsequent full market launch (e.g., the role of the manufacturer's market resources and dealers).

In this phase, the strongest emphasis was on the dealer-user dyad and how the value proposition would materialize in markets and for different users. The traditional value proposition between the dealer and user focused on product performance and technical 
features, rather than on process-related issues, such as optimizing the customer's fleet. The triadic value proposition instead became more reciprocal, with contributions from the user, dealer, and manufacturer, and it also introduced more flexibility (e.g., customization). Furthermore, interdependence across the triad increased, such as when a value proposition between user and manufacturer (e.g., work technique improvements) affected the value proposition between dealer and user (e.g., users learned new work techniques and thus could contribute to analyses). As one of the users acknowledged,

We can identify teams that do not handle the machines correctly ... and we can then train them better... (Manager, User firm)

The manufacturer-dealer dyad also was scrutinized to determine which actor should provide which resources during the materialization of the value proposition in the market.

Throughout the development of this triadic value proposition, the ties among the actors developed in several ways. For example, the manufacturer was the initiator, yet the dealers had to materialize the value proposition, which strengthened their network ties with users as these dealers became more involved in users' business process and their value proposition focused more on value-in-use. A similar effect on manufacturer-user ties was somewhat weaker though, because the manufacturer was not directly responsible for the materialization of the value proposition. Table 4 describes these network ties following the initiation of the new triadic value proposition.

\section{--INSERT TABLE 4 HERE-}

\subsection{Dyad 1: Manufacturer and dealer}

The dealers were responsible for materializing the new value proposition, so they needed to be incentivized to take leading roles. That is, the manufacturer had to design an attractive value proposition that encouraged the dealer to work proactively with service offerings. The new value proposition accordingly included several benefits for the dealers' 
business. First, performing maintenance on a planned and regular basis (cf. reactively) gave the dealer more predictability and more billable service hours, along with associated spare part sales. Second, the manufacturer indirectly supported the dealers' business processes with various online tools, such as a value calculator to reveal the potential for increased machine sales, spare part sales, and better scheduling of workshop resources. Third, the new value proposition emphasized the dealer's potential to become a more important business partner to users. Dealers appreciated this support, especially as they perceived increased pressure from users in relation to lifecycle costs:

How long is the machine lasting? How long they can use it without troubles? It's very important nowadays, that they [the user] know it's very stable, because they realize more than ever, I believe, that they have to come back here, and it's time consuming, and it's really taking their margin. (Manager, Dealer)

Finally, the new value proposition added value for the manufacturer, through increased new product and spare part sales, as well as increased brand loyalty in the multibrand dealer network. The value proposition thus was reciprocal, with potential value for both actors and the need for resources from both manufacturer (e.g., technology, web portal, training) and dealer (e.g., time, workshop resources, user knowledge).

\subsection{Dyad 2: Dealer and user}

A focal goal in the value proposition between dealers and users was to minimize users' machine downtime by performing preventive maintenance and optimizing their machines fleets. Minimizing downtime promises lower costs and increased revenues, but users traditionally ran the machines until they broke down, and then the dealer reactively repaired them: 
We try to do as little as possible, since we believe the dealer does the service and repairs better than we do. It's expensive for us to work with the machines. Instead, we just turn them in to the dealer. (Manager, User firm)

This issue was costly and time consuming for both actors, especially during peak demand times, when the dealer struggled to manage customer requests efficiently and on time. It was important to motivate users to contribute their own resources to fulfill this value proposition, which would reduce costs associated with transporting machines or production halts.

The biggest potential that I can see is perhaps that of increasing the productivity of each machine and to do more preventive maintenance in order to reduce repair costs. (Manager, User firm)

The down-time [of the machines] kills you (Manager, User firm)

Dealers also acknowledged this shift toward an uptime focus:

[Users] don't want to spend more time on maintenance and things like that. They like to get rid of that ... they just want it to work. (Manager, Dealer)

For the dealer, minimizing user downtime meant taking more responsibility for materializing and customizing the value proposition for each user's specific business processes, because downtime reflects the specific user context (e.g., maintenance strategy, employee machine handling, procurement processes). To fulfill the value proposition, both actors needed to align their resources and perform certain activities, such as maintenance planning by the dealer (e.g., wireless sensors, web-based fleet support) or administering the online account and updating information in the system by the user. The value proposition also encouraged users to adopt a systematic repair and preventive maintenance plan to avoid costly breakdowns. The maintenance plan increased service-related business for the dealer but also minimized machine downtime for the user, because services became more preventive than reactive and thus improved the utilization rate for the user fleet. 


\subsection{Dyad 3: Manufacturer and user}

The dyadic relationship between the manufacturer and user changed significantly in the triadic value proposition. Previously, the user had focused almost exclusively on the dealer's value proposition and effectively had no ties to the manufacturer. The emergence of the triadic value proposition strengthened those ties:

I'm surprised, in a good way, that the manufacturer takes responsibility for our issues and proposes solutions to resolve some of them. (Manager, User firm)

The embedded manufacturer-user dyad contained different elements of reciprocity and mutual value creation, and the focus of the value proposition was an ability to gather and analyze user and usage data before presenting this information to the user. That is, users could manage their own fleet and individual machines, as well as individual operators, in real time, after receiving information about machine usage, potential wear, and individual operators' work techniques. Then the manufacturer could strengthen this relationship by offering added supporting services, such as technique training, illustrated parts lists, or owner and workshop manuals. One customer referred to the new links to the manufacturer as ... a win-win-situation. You [the manufacturer] have developed it [the new offering] and brought it to the market, and we can through this maintain our machine better.... With this system, we know when the machines are in need of maintenance. Right now we're just guessing. (Manager, User firm)

This last comment also points to the other side of the (reciprocal) value proposition, because the manufacturer needed to capture some of the value created, as was manifested in increased product sales, along with direct links to and more knowledge of users and their product usage. With the new value proposition, the manufacturer thus was able to convert some previously multibrand customers to fleets that consist of only this manufacturer's brand. 
To be materialized, the value proposition required resource contributions from both the manufacturer and users. The manufacturer's most significant contribution was the technology to set up the interactive channel and collect and analyze user product and process data. For example, the manufacturer helped the user operate more efficiently by providing an online library that included all registered spare parts and videos with training material. To realize the full promise of this value, it needed active user participation and feedback. Users in turn actively discussed fleet optimization with the manufacturer, in terms of logged machine-hours, and actively analyzed work techniques with dealers, based on real-time data.

\section{Discussion}

We will now discuss the dynamics of value propositions before considering more specifically how a new-to-the-industry offering can change a triad from intransitive to transitive.

\subsection{Value proposition dynamics}

The emergence of new and increasingly networked business models, such as service triads (Wynstra et al. 2015), hybrid business models (Teece 2010), industrial service channels (Nordin et al. 2013), and collaborative alliances (Wu et al. 2010), highlights the limitations of considering only dyadic value propositions. As our case illustrates, a traditional dyadic perspective on value propositions is insufficient when actors other than the supplier firm have user relationships, such as when a manufacturer has no local market presence and operates through dealers. In such settings, throughout their lifecycle, products get sold and serviced by actors other than the manufacturer. Any move to enter the service market means that the manufacturer must devise incentives for the user to purchase the service but also for the intermediary to promote and commit to this new market offering. As the value proposition grows more complex - in this case, moving from product sales and spare parts provision to more advanced services and increased interaction — it becomes necessary to conceptualize the value proposition as a promise of value among the manufacturer, dealer, and user, rather than 
as two distinct dyadic value propositions (manufacturer-dealer and manufacturer-user) in an intransitive triad. If the promise of value changes between two actors, it affects the promise of value for (and value alignment of) the third actor. In line with recent extensions of the value proposition concept (see Appendix 1), triadic value propositions can facilitate value alignment, because they offer a tangible signal of the value potential eventually to be shared among the three actors, as illustrated by a user we interviewed:

The biggest thing with the new value proposition is the focus on long-term relationships and maintenance. (Manager, User firm)

Compared with a supplier-focused, dyadic value proposition, a triadic value proposition stipulates a greater focus on including multiple actors in a reciprocal value creation process, emphasizing and structuring their roles rather than following a unidirectional process emanating from the manufacturer. The manufacturer's Director of Services, assessing the new situation from the customer's point of view, notes:

It is interesting that you as a customer have a close relationship and cooperation with your dealer and it is interesting how we [the manufacturer] can benefit from this.... The dealer will become more of a partner for you as customer and sell more advanced service to you. I think it is a win-win-win situation... The main relation will be between the dealer and the user. However, we will also be present to see whether the system works or not, and whether modifications are needed.

It then follows that all actors must play more active roles in the value creation process. From the manufacturer's perspective, this result opens the previously opaque black box of the user and stimulates interaction points and network ties that did not exist previously. In our study context, which featured relatively passive users, this perspective transforms the role of users to active participants, changing their business processes and contributing to the value creation 
process by both providing information and dedicating resources to materializing the value proposition as value-in-use.

When introducing this triadic value proposition, a major change was the establishment of direct ties between the manufacturer and users. The triadic value proposition, which included the user, enabled the manufacturer to strengthen its position in the user market by encouraging manufacturer-user interactions and increasing brand awareness. It also affected the dyadic dealer-user and manufacturer-dealer ties, thereby reframing the dyadic relationships embedded in the transitive triad (see Table 4).

These findings resonate with Frow and Payne's (2011) idea that firms need to offer value propositions to all stakeholders. Any actor can initiate a value proposition (Ballantyne et al. 2011; Kowalkowski 2011), but the present case illustrates a typical situation of a supplier-initiated value proposition. The triadic value proposition concept also aligns well with Storbacka and Nenonen's (2011) views on market propositions and scripting markets: As value is increasingly co-created in networks, in market practices participated by several actors, the argument could be that "the firm offers market propositions," signifying that successful firms need to offer their subjective view on how the market should be configured and engage actors in collective sense making (Weick 1995) activities aimed at creating a shared market view. (p. 259) To be successful, the triadic value proposition needs a higher "intensity" level, such that the invitation to engage is more relevant to an actor (Chandler and Lusch 2015). In our case, their eventual acceptance of the value proposition (after several iterations, the phases described, and mutual adaptations over the years) required the dealers to act beyond their traditional comfort zone of product sales. The dealers thus needed to develop new resources and competences and a new way of thinking about their role in the value constellation — that is, a 
new mental model. An important part of gaining dealers' acceptance of the value proposition was the need to enable and facilitate learning and increased understanding of users.

Finally, the triadic value proposition exemplifies how a firm can manage an indirect market channel. Nordin et al. (2013) discuss disintermediation, or “an organization's adoption of various mechanisms for handling intermediaries, aimed at securing links with end customers" (p. 180). In the present case, three of the six disintermediation mechanisms that Nordin et al. (2013) describe played a vital role in developing the triadic value proposition: communication and training (influencing dealers and users and exchanging information and instructions throughout the triad); incentives to encourage the intermediary (and user) to act appropriately; and information and communication technology (ICT).

\subsection{Transitive triads through service innovation}

As a manufacturer introduces services to its portfolio, more than just the manufacturer-intermediary or intermediary-user value propositions change. New types of service innovation imply more complex interorganizational patterns and require new competences and skills, such as local knowledge of and relationships with users, as well as a local service network. This demand is particularly pertinent in an indirect market channel with independent intermediaries (e.g., dealers). Matthyssens and Vandenbempt (2008) show that firms that increasingly offer service-based value must interact and develop relationships with not just customers but other downstream actors too. Finne and Holmström (2013) find that service innovation can take place at the supply chain level, involving several actors at multiple levels. Even as most studies of service innovation adopt a dyadic perspective, there have been calls to look beyond the dyad (Finne and Holmström 2013; Gebauer et al. 2013; Kowalkowski et al. 2013; Windahl and Lakemond 2006). In reality, many small and local, as well as multinational, manufacturers operate through intermediaries (Nordin et al. 2013), which extends the dyad to include more actors in the network. It may be costly for 
manufacturers to equip dealers with the competences to perform the proposed services (Wynstra et al. 2015), but these relationships can be greatly enhanced through multilateral learning and knowledge sharing (Nätti et al. 2014).

Our findings emphasize the importance of deepening the relationship between manufacturer and dealers, such as through structural, technical, social, and relational dimensions. In our case, this process entailed a range of mechanisms, including educational activities, web-based systems, and incentive schemes. Prior service innovation research has indicated that if manufacturing firms are to compete on the basis of their industrial services, they need an in-house service organization and infrastructure to respond to local service demands (e.g., Gebauer and Kowalkowski 2012; Neu and Brown 2008; Oliva and Kallenberg 2003). Yet the creation of an in-house service network may be unfeasible, due to the strong market position of dealers or the significant investment and operating costs such an expansion would necessitate. In these cases, firms cannot view intermediaries as a "necessary evil" or an obstacle to business development but rather should acknowledge them as another type of customer, similar to "internal customers" on which internal marketing focuses, and include them accordingly when crafting value propositions.

The notion of internal marketing has long been acknowledged as integral to marketing (Grönroos 1978); it is as indispensable as external and interactive forms geared toward customers or users, especially if manufacturers seek to succeed with new service initiatives. Such a change requires employees to deal with customers in service-oriented ways, changing the model from reactive order-taking to proactive value creation through relational business engagement. Similarly, firms may need to extend their internal marketing efforts to other critical actors in the value constellation, using what might be termed "intermediary marketing." For example, the manufacturer we study actively included dealers in the development of the value proposition through multiple workshops and concept-testing 
activities, as well as formal training. In turn, dealers became part of the new value proposition, which increased their commitment and improved their ability to materialize the value proposition in the market.

Finally, this study demonstrates the importance of developing structural and economic relationship dimensions alongside social and relational ties, which lead to better understanding of other actors' businesses and intangible values. This broad view is apparent in the triadic value proposition, where stronger network ties enable a shift from an intransitive to a transitive triad. Economic incentives are prerequisites for the viability of the new value proposition; stronger structural and technical ties are essential to enable its implementation and secure commitments. To foster deeper relationships, social and relational ties again are crucial. Technical ties might enable information exchange, but social and relational ties create the long-term orientation, trust, and commitment needed for knowledge sharing. As studies of asymmetrical information exchange show (Mascarenhas et al. 2008), balanced knowledge sharing and symmetrical information exchange is vital to the success of value constellations and propositions.

\section{Conclusions and implications}

In this final section, we discuss the scientific and practical utility of the study, followed by limitations and directions for further research.

\subsection{Theoretical implications}

The triadic structure is an important aspect of business networks in management and marketing literature (e.g., Madhavan et al. 2004; Nätti et al. 2014; Wynstra et al. 2015). By adopting a systemic network perspective on value creation, value propositions help identify the distribution of value in a value constellation or service system (Frow and Payne 2011). As we illustrate, a focus on dyadic settings may be limiting and inadequate for explaining discontinuous innovations such as the introduction of new-to-the-industry service initiatives, 
which affect the network ties of all actors embedded in the triad. A viable value proposition demands alignment among the interests of all actors in the system.

Although value constellations clearly may consist of more than three actors, the triadic structure is an important element in network analysis, between the single dyad and the overall network structure (Madhavan et al. 2004). As Choi and Wu (2009b, p. 265) argue, "We need to study how in a network, a dyad is affected by another dyad. Therefore, to study a network, studying triads becomes imperative.... Simply, dyads are inadequate in capturing the interactive nature inherent in a network." The utility of a triadic analysis is not confined to industrial service channels; it can be equally important for understanding phenomena such as competitor alliance networks involving buyer-supplier-supplier triads (Wu et al. 2010) or customer-buyer-supplier triads, in which a buyer contracts with a supplier to deliver services directly to its customer (Wynstra et al. 2015). These examples of emerging networked business models are of interest both for practical purposes and as research topics.

We contribute to theories of both value propositions and service business development by showing how different dimensions of the value proposition and network ties change as manufacturers extend their portfolio through service-led growth. We thereby respond to one of the priority themes for service research (i.e., developing service networks and systems) as described by Ostrom et al. (2015) and the emerging field of service science (IfM and IBM 2008). That is, we analyze the dynamics of value propositions connecting service systems. In particular, this study responds to the calls by Frow et al. (2014) and Kowalkowski (2011) for a detailed study of how multilateral value propositions develop and evolve over time, focusing on the roles of each actor and the mechanisms for integrating actors' various resources. Finally, the present study confirms Frow et al.'s (2014, p. 344) view of value propositions as alignment mechanisms "through which actors offer and attract resources," arising "from the potential inherent in actors' resources" and also determining 
how and with whom actors choose to engage, such that they shape market interactions. In turn, we extend applications of value propositions to a wider range of stakeholders in valuecreating systems.

From a service management perspective, the present study addresses calls to extend the study of service innovation in manufacturing firms beyond a common but limited dyadic perspective. Many manufacturers depend on channel intermediaries for service provision, so a dyadic perspective is generally insufficient, and a broader, multilateral view of value propositions is required. Our findings highlight the importance of deepening relationships with service channel intermediaries through mechanisms such as ICT, communication, training, and new incentives to encourage the intermediary. The concept of the triadic value proposition also is helpful in developing insights into value co-creation processes as they apply to relationships beyond the buyer-supplier dyad.

\subsection{Managerial implications}

In terms of its practical contributions, this study shows how triadic value propositions may shape new possibilities for resource integration in the service system, beyond dyadic settings. From a managerial perspective, a dyadic focus on customer relationships and value propositions is insufficient for most firms; for example, as manufacturing firms move toward increased service provision, they seldom encounter an "empty space" for services in their market channel. Rather, the services are already provided (even if not necessarily identical to or addressing the same values as the new service), so the manufacturer must relate to this competitive actor as well. Extending beyond the buyer-supplier dyad should provide more integrated opportunities for co-creating and co-influencing value propositions. This wider perspective suggests how firms can benefit by adopting a broader view of value creation through the development of multilateral value propositions that address the interests of all actors in the value constellation. 
A wider perspective also promises previously unrealized business outcomes. With an increased emphasis on the user and its business processes, both manufacturers and dealers can create opportunities for sustainable differentiation. As arose for the manufacturer in this case, another potential outcome is an enhanced market position, by establishing new ties and a clearer market presence. By activating users as well as dealers, the more interactive process can prompt intensive information sharing and knowledge creation. An explicit value proposition development process also should lead to increased loyalty across the triad and a more viable value constellation. From a service innovation perspective, this study is interesting, in that (1) the manufacturer was not a product leader when entering the service business and (2) dealers sold multiple brands, with no specific loyalty to any particular manufacturer. By adopting a triadic perspective when crafting its value proposition, the manufacturer was able to shape the network ties in the value constellation to make it viable.

The level of abstraction and complexity also increases when value propositions are conceptualized as triadic, in that dyads are embedded in triads. To make the concept more actionable, managers might follow the approach by Ballantyne et al. (2011) to crafting of reciprocal value propositions, which recommends using a form that emphasizes

"If we ..." (stated in terms of benefits promised for the beneficiary), "will you ..." (stated in terms of the benefits expected for the focal company). What is important is the intent to offer something of value to another party and the subsequent creative conversations, dialogue and adaptations that follow from this initial expression. (p. 206)

Figure 2 provides illustrative examples of such reciprocal value propositions, from a manufacturer's perspective: manufacturer to dealer, manufacturer to user, and dealer to user. Crafting a value proposition allows the actors, and the initiating firm in particular, to focus on both the practices (the process) and the intention (expected outcome). In practice, the crafting 
process likely is incremental, as in our case study; the more discontinuous and innovative the proposition, the more time and iterations may be required.

\section{--INSERT FIGURE 2 HERE--}

The value propositions in Figure 2 might appear straightforward, yet they are the results of substantial work over time, involving managers from leading dealers and users. The original draft value propositions were revised several times. From a network perspective, a key challenge thus is that any adjustment in the arrangement of two parties may influence what can be proposed to the third. Previous research on business development and innovation highlights the crucial role of lead users when firms intend to collaborate with rather than bypass an intermediary, but major effort also is needed to identify and work with "lead intermediaries.” In service systems at least, it typically takes at least three to tango.

\subsection{Limitations and research directions}

Like any research, our findings are limited by our methodological approach and the type of data gathered. Some of these limitations offer avenues for research on value propositions. Further studies could analyze the influence of network ties on the viability of the value proposition in more depth, as well as evaluating the long-term effects of new value propositions. This study was conducted in a capital equipment manufacturing context, but triadic value propositions clearly have relevance in other industries and value constellations, such as ICT with its complex networks of software, hardware, and service providers (e.g., Google offers distinct value propositions to its users versus advertisers). Another interesting direction would be to link triadic value propositions to hybrid business models, in which companies both collaborate and compete with their partners by providing similar offerings to end users. Companies have attempted to morph to hybrid business models in industries such as credit card provision (Teece 2010) and industrial services (Nordin et al. 2013). To gain more specific insights into the dynamics of value propositions in service systems and make 
cross-industry comparisons, more empirical studies should investigate diverse contexts.

Scholars also could take a further step by analyzing multilateral value propositions with additional actors, such as four-way relationships with separate dealers and service partners. We hope this work stimulates new conceptualizations and research in this theoretically and managerially relevant research domain. 


\section{References}

Achrol RS (1997) Changes in the theory of interorganizational relations in marketing: toward a network paradigm. Journal of the Academy of Marketing Science 25(1): 56-71.

Anderson JC, Kumar N, Narus JA (2007) Value merchants: Demonstrating and documenting superior value in business markets (Harvard Business School Press, Boston MA).

Anderson JC, Narus JA, van Rossum W (2006) Customer value propositions in business markets. Harvard Business Review 84(3): 90-99.

Ballantyne D (2003) A relationship mediated theory of internal marketing. European Journal of Marketing 37(9): 1242-1260.

Ballantyne D, Frow P, Varey RJ, Payne A (2011) Value propositions as communication practice: Taking a wider view. Industrial Marketing Management 40(2): 202-210.

Ballantyne D, Varey RJ (2006) Creating value-in-use through marketing interaction: the exchange logic of relating, communicating and knowing. Marketing Theory 6(3): 335-348.

Basole RC, Karla J (2014) Value transformation in the mobile service ecosystem: A study of app store emergence and growth. Service Science 4(1): 24-41.

Chandler JD, Lusch RF (2015) Service systems: A broadened framework and research agenda on value propositions, engagement, and service experience. Journal of Service Research 18(1): 6-22.

Choi TY, Wu Z (2009a) Go ahead, leap: triads and their practical and theoretical import: in response to "To leap or not to leap: triads as arbitrary subsets of networks of connected dyads" by Anna Dubois. Journal of Purchasing and Supply Management 15(4): 269-270.

Choi TY, Wu Z (2009b) Taking the leap from dyads to triads: Buyer-supplier relationships in supply networks. Journal of Purchasing and Supply Management 15(4): 263-266.

Coleman JS (1958) Relational analysis: The study on social organization with survey methods. Human Organization 17: 28-36. 
Corsaro D, Ramos C, Henneberg SC, Naudé P (2012) The impact of network configurations on value constellations in business markets-The case of an innovation network. Industrial Marketing Management 41(1): 54-67.

Cova B, Salle R (2008) Marketing solutions in accordance with the S-D logic: Co-creating value with customer network actors. Industrial Marketing Management 37(3): 270-277. Covin JG, Garret RP, Kuratko, DF, Shepherd DA (2015) Value proposition evolution and the performance of internal corporate ventures. Journal of Business Venturing 30(5): 749-774.

Dubois A, Gadde LE (2002) Systematic combining: An abductive approach to case research. Journal of Business Research 55(7): 553-560.

Dyer JH, Nobeoka K (2000) Creating and managing a high performance knowledge-sharing network: the Toyota case. Strategic Management Journal 21(3): 345-368.

Eisenhardt KM (1989) Building theory from case study research. Academy of Management Review 14(4): 532-550.

Finne M, Holmström J (2013) A manufacturer moving upstream: triadic collaboration for service delivery. Supply Chain Management: An International Journal 18(1): 21-33.

Ford D (2011) IMP and service-dominant logic: Divergence, convergence and development. Industrial Marketing Management 40(2): 231-239.

Flint DJ, Mentzer JT (2006) Striving for integrated value chain management given a servicedominant logic for marketing. In Lusch RF, Vargo SL (Eds.), The Service-Dominant Logic of Marketing: Dialog, Debate, and Directions: 139-149. (ME Shape, Armonk, NY).

Ford D, Håkansson H, Johanson J (1986) How do companies interact? Industrial Management \& Purchasing 1(1), 339-354.

Frow P, McColl-Kennedy JR, Hilton T, Davidson A, Payne A, Brozovic D (2014) Value propositions: A service ecosystems perspective. Marketing Theory 14(3): 327-351. 
Frow P, Payne A (2011) A stakeholder perspective of the value proposition concept. European Journal of Marketing 45(1/2): 223-240.

Garcia R, Calantone R (2002) A critical look at technological innovation typology and innovativeness terminology: a literature review. Journal of Product Innovation Management 19: $110-132$.

Gebauer H, Kowalkowski C (2012) Customer-focused and service-focused orientation in organizational structures. Journal of Business and Industrial Marketing 27(7): 527-537.

Gebauer H, Paiola M, Saccani N (2013) Characterizing service networks for moving from products to solutions. Industrial Marketing Management 42(1): 31-46.

Gibbert M, Ruigrok W, Wicki B (2008) What passes as a rigorous case study? Strategic Management Journal 29(13): 1465-1474.

Gomes-Casseres B (1994) Group vs. group: How alliance networks compete. Harvard Business Review 72(4): 62-67.

Grönroos C (1978) A service-orientated approach to marketing of services. European Journal of Marketing 12(8): 588-601.

Grönroos C (2008) Service-dominant logic revisited: Who creates value? And who cocreates? European Business Review 20(4): 298-314.

Grönroos C, Gummerus J (2014) The service revolution and its marketing implications: Service logic vs. service-dominant logic. Managing Service Quality 24(3): 206-229. Gummesson E (2000) Qualitative Methods in Management Research (Sage Publications, Thousand Oaks CA).

Håkansson H, Ford D (2002) How should companies interact in business networks? Journal of Business Research 55(2): 133-139.

Håkansson H, Snehota I (1995) Developing Relationships in Business Networks (Routledge, London). 
Halinen A, Törnroos J-A (2005) Using case methods in the study of contemporary business networks. Journal of Business Research 58: 1287-1297.

Havila V, Johanson J, Thilenius P (2004) International business-relationship triads. International Marketing Review 21(2): 172-186.

Holma A (2010) Relationship development in business triads - Case studies in corporate travel management. Journal of Business Market Management 4(2): 73-90.

Holmlund M, Strandvik T (1999) Perception configurations in business relationships. Management Decision 37(9): 686-696.

Holmlund M, Törnroos JÅ (1997) What are relationships in business networks? Management Decision 35(4): 304-309.

IfM, IBM (2008) Succeeding through service innovation: A service perspective for education, research, business and government, University of Cambridge Institute for Manufacturing, Cambridge, UK.

Karmarkar US, Roels G (2015) An analytical framework for value co-production in services. Service Science 7(3): 163-180.

Kelleher JB (2014) From dumb iron to Big Data: Caterpillar's dealer sales push. Reuters Business News, 20 March 2014.

Kingman-Brundage J, George WR, Bowen DE (1995) Service logic: achieving service system integration. International Journal of Service Industry Management 6(4): 20-39. Kovács G, Spens KM (2005) Abductive reasoning in logistics research. International Journal of Physical Distribution \& Logistics Management 35(2): 132-144.

Kowalkowski C (2011) Dynamics of value propositions: Insights from service-dominant logic. European Journal of Marketing 45(1): 277-294. 
Kowalkowski C, Persson Ridell O, Röndell JG, Sörhammar D (2012) The co-creative practice of forming a value proposition. Journal of Marketing Management 28(13-14): 15531570.

Kowalkowski C, Witell L, Gustafsson A (2013) Any way goes: Identifying value constellations for service infusion in SMEs. Industrial Marketing Management 42(1): 18-30. Lempinen H, Rajala R (2014) Exploring multi-actor value creation in IT service processes. Journal of Information Technology 29: 170-185.

Levina N, Ross JW (2003) From the vendor's perspective: Exploring the value proposition in information technology outsourcing. MIS Quarterly 27(3): 331-364.

Lusch RF, Webster FE (2011) A stakeholder-unifying, cocreation philosophy for marketing. Journal of Macromarketing 31(2): 129-134.

Madhavan R, Gnyawali DR, He J (2004) Two's company, three's a crowd? Triads in cooperative-competitive networks. Academy of Management Journal 47(6): 918-927. Maglio PP, Spohrer J (2008) Fundamentals of service science. Journal of the Academy of Marketing Science 36(1): 18-20.

Martos-Partal, M, González-Benito, O, Fustinoni-Venturini, M (2015) Motivational profiling of store brand shoppers: Differences across quality tiers. Marketing Letters 26(2): 187-200. Mascarenhas O, Kesavan R, Bernaccchi M (2008) Buyer-seller information asymmetry: challenges to distributive and corrective justice. Journal of Macromarketing 28(1): 68-84. Matthyssens P, Vandenbempt K (2008) Moving from basic offerings to value-added solutions: Strategies, barriers and alignment. Industrial Marketing Management 37(3): 316328.

McDermott CM (1999) Managing radical product development in large manufacturing firms: A longitudinal study. Journal of Operations Management 17(6): 631-645. 
Möller K, Svahn S (2006) Role of knowledge in value creation in business nets. Journal of Management Studies 43(5): 985-1007.

Nätti S, Pekkarinen S, Hartikka A, Holappa T (2014) The intermediator role in value cocreation within a triadic business service relationship. Industrial Marketing Management 43(6): 977-984.

Neu WA, Brown SW (2008) Manufacturers forming successful complex business services: Designing an organization to fit the market. International Journal of Service Industry Management 19(2): 232-251.

Nordin F, Brozovic D, Holmlund M (2013) Disintermediation mechanisms in industrial service channels: Mechanisms and challenges. Journal of Business-to-Business Marketing 20(4): 179-192.

Normann R (1970) A Personal Quest for Methodology (Scandinavian Institute for Administrative Research, Stockholm).

Normann R (2001) Reframing Business—When the Map Changes the Landscape (John Wiley \& Sons, Chichester, UK).

Normann R, Ramírez R (1994) Designing Interactive Strategy: From Value Chain to Value Constellation (John Wiley \& Sons, Chichester, UK).

Oliva R, Kallenberg R (2003) Managing the transition from products to services. International Journal of Service Industry Management 14(2): 160-172.

Olkkonen R, Tuominen P (2008) Fading configurations in inter-organizational relationships: a case study in the context of cultural sponsorship. Journal of Business \& Industrial Marketing 23(3): 203-212.

Ostrom, AL, Parasuraman A, Bowen DE, Patrício L, Voss CA (2015) Service research priorities in a rapidly changing context. Journal of Service Research 18(2): 127-159. 
Payne A, Frow P (2014a) Deconstructing the value proposition of an innovation exemplar. European Journal of Marketing 48(1/2): 237-270.

Payne A, Frow P (2014b) Developing superior value propositions: a strategic marketing imperative. Journal of Service Management 25(2): 213-227.

Payne AF, Storbacka K, Frow P (2008) Managing the co-creation of value. Journal of the Academy of Marketing Science 36(1): 83-96.

Pettigrew AM (1987) Context and action in the transformation of the firm. Journal of Management Studies 24(6): 649-670.

Pettigrew AM (1990) Longitudinal field research on change: theory and practice.

Organization Science, 1(3): 267-292.

Rajala R, Töytäri P, Hervonen T (2015) Assessing customer-perceived value in industrial service systems. Service Science, 7(3): 210-226.

Ramírez R (1999) Value co-production: intellectual origins and implications for practice and research. Strategic Management Journal 20(1): 49-65.

Ritter T (2000) A framework for analyzing interconnectedness of relationships. Industrial Marketing Management 29(4): 317-326.

Salo A, Tähtinen J, Ulkuniemi P (2009) Twists and turns of triadic business relationship recovery. Industrial Marketing Management 38(6): 618-632.

Siltaloppi J, Vargo SL (2014) Reconciling resource integration and value propositions - the dynamics of value co-creation. Proceedings of the 47th Hawaii International Conference on System Science, Waikoloa, HI: 1278-1284.

Skålén P, Gummerus J, von Koskull C, Magnusson PR (2014) Exploring value propositions and service innovation: a service-dominant logic study. Journal of the Academy of Marketing Science 43(2): 137-158. 
Stewart DW, Shamdasani PN (2014) Focus Groups: Theory and Practice (Vol. 20) (Sage, Thousand Oaks, CA).

Storbacka K, Nenonen S (2011) Scripting markets: From value propositions to market propositions. Industrial Marketing Management 40(2): 255-266.

Teece D (2010) Business models, business strategy and innovation. Long Range Planning 43: $172-194$.

Treacy M, Wiersema F (1995) The discipline of market leaders (Addison-Wesley, Reading MA).

Truong Y, Simmons G, Palmer M (2012) Reciprocal value propositions in practice:

Constraints in digital markets. Industrial Marketing Management 41(1): 197-206.

Vargo SL, Akaka MA (2009) Service-dominant logic as a foundation for service science: Clarifications. Service Science 1(1): 32-41.

Vargo SL, Lusch RF (2004) Evolving to a new dominant logic for marketing. Journal of Marketing 68(January): 1-17.

Vargo SL, Wieland H, Archpru Akaka M (2015) Innovation through institutionalization: A service ecosystems perspective. Industrial Marketing Management 44(1): 63-72.

Webster FE (2002) Market-driven management: how to define, develop, and deliver customer value (John Wiley \& Sons, Hoboken NJ).

Weick KE (1995) Sensemaking in organizations (Sage, Thousand Oaks, CA).

Windahl C, Lakemond N (2006) Developing integrated solutions: the importance of relationships within the network. Industrial Marketing Management 35(7): 806-818. Woodside AG, Wilson EJ (2003) Case study methods for theory building. Journal of Business \& Industrial Marketing 18(6/7): 493-508. 
Wu Z, Choi TY, Rungtusanatham MJ (2010) Supplier-supplier relationships in buyersupplier-supplier triads: Implications for supplier performance. Journal of Operations Management 28(2): 115-123.

Wynstra F, Spring M, Schoenherr T (2015) Service triads: a research agenda for buyersupplier-customer triads in business services. Journal of Operations Management, 35: 1-20. Yin RK (2003) Case Study Research: Design and Methods (Sage, Thousand Oaks CA). 


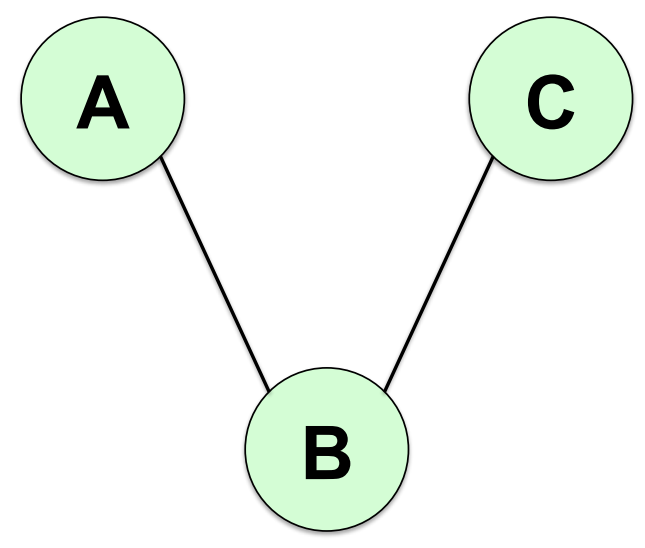

1a. Intransitive triad

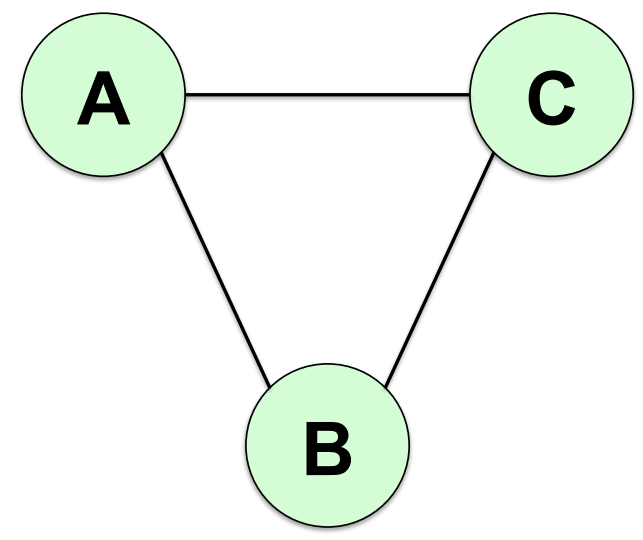

1b. Transitive triad

Figure 1. Triads in business networks

If we, together with your dealer, set up a system for managing your fleet and minimizing your downtime, will you work together with us to enable more professional management of your business?

If you commit the time and resources to learn, develop, and maintain this new service concept, we will support you with technology, training, and infrastructure and provide costefficient solutions for your business

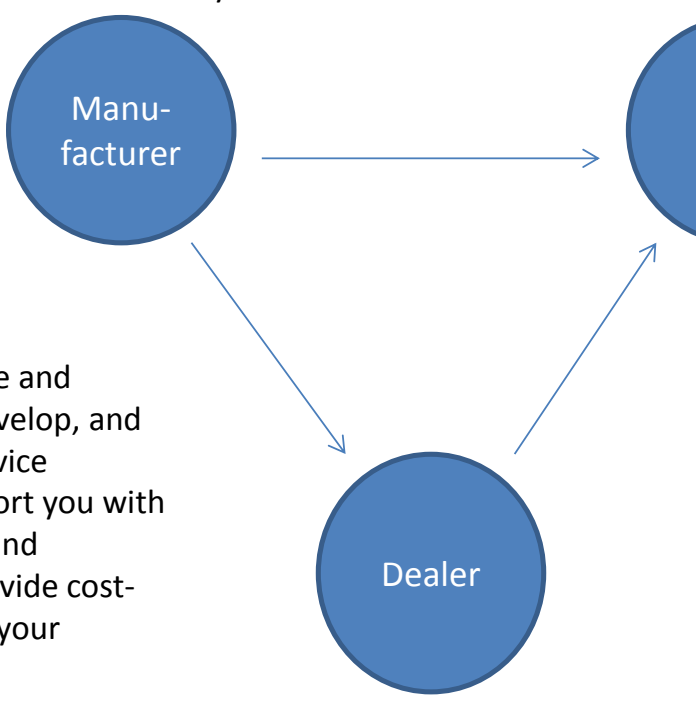

User

If we set up and organize a solution to minimize your downtime and costs of ownership, will you follow the maintenance program?

Figure 2. Sample reciprocal promises in a manufacturer-initiated triadic value proposition 
Table 1. Respondents

\begin{tabular}{|l|l|l|l|}
\hline Actor & $\begin{array}{l}\text { Number of } \\
\text { Interviews }\end{array}$ & Roles & Time Frame \\
\hline Manufacturer & 12 & $\begin{array}{l}\text { Director service solutions, Marketing manager, } \\
\text { Innovation manager, Global sales manager, } \\
\text { Regional sales managers }\end{array}$ & $2006-2014$ \\
\hline Dealers & 11 & $\begin{array}{l}\text { Owners/managing directors, service technicians, } \\
\text { sales }\end{array}$ & $2008-2014$ \\
\hline Users & 26 & $\begin{array}{l}\text { Owners/managing directors, service technicians, } \\
\text { operators }\end{array}$ & $2008-2014$ \\
\hline
\end{tabular}

Table 2. Research process.

\begin{tabular}{|c|c|c|c|c|}
\hline Timeframe & 2004-2009 & 2009-2012 & 2012-2014 & 2014 \\
\hline $\begin{array}{l}\text { Key } \\
\text { manufacturer } \\
\text { activities }\end{array}$ & $\begin{array}{l}\text { Forming service } \\
\text { idea, developing } \\
\text { initial value } \\
\text { proposition, initial } \\
\text { user study }\end{array}$ & $\begin{array}{l}\text { Pilot run with } \\
\text { selected users, } \\
\text { detailed user study, } \\
\text { preliminary dealer } \\
\text { input, technology } \\
\text { development }\end{array}$ & $\begin{array}{l}\text { Extended pilot launch } \\
\text { (multiple markets), } \\
\text { workshops with all } \\
\text { actors, technology } \\
\text { development }\end{array}$ & $\begin{array}{l}\text { Early market launch } \\
\text { in selected markets, } \\
\text { development of } \\
\text { support material, } \\
\text { technology } \\
\text { development, } \\
\text { extension of value } \\
\text { proposition to } \\
\text { additional product } \\
\text { range }\end{array}$ \\
\hline $\begin{array}{l}\text { Key research } \\
\text { activities }\end{array}$ & $\begin{array}{l}\text { Manufacturer } \\
\text { focus group, } \\
\text { manufacturer } \\
\text { interviews, user } \\
\text { interviews, dealer } \\
\text { interviews }\end{array}$ & $\begin{array}{l}\text { Manufacturer focus } \\
\text { group, } \\
\text { manufacturer } \\
\text { interviews }\end{array}$ & $\begin{array}{l}\text { Workshops with all } \\
\text { actors, manufacturer } \\
\text { interviews, user } \\
\text { interviews, dealer } \\
\text { interviews }\end{array}$ & $\begin{array}{l}\text { Manufacturer focus } \\
\text { group, manufacturer } \\
\text { interviews, dealer } \\
\text { interviews, user } \\
\text { interviews }\end{array}$ \\
\hline $\begin{array}{l}\text { Example } \\
\text { outcomes of the } \\
\text { research process }\end{array}$ & $\begin{array}{l}\text { Understanding the } \\
\text { initial value } \\
\text { proposition as well } \\
\text { as the market } \\
\text { context }\end{array}$ & $\begin{array}{l}\text { Understanding the } \\
\text { internal } \\
\text { development } \\
\text { process of the value } \\
\text { proposition }\end{array}$ & $\begin{array}{l}\text { Understanding the } \\
\text { market launch process } \\
\text { and demands of } \\
\text { multiple stakeholders }\end{array}$ & $\begin{array}{l}\text { Understanding the } \\
\text { market launch } \\
\text { process and } \\
\text { continuous } \\
\text { development of the } \\
\text { value proposition }\end{array}$ \\
\hline
\end{tabular}


Table 3. Network ties in the intransitive triad

\begin{tabular}{|l|l|l|l|}
\hline Tie & Structural and Technical & Economic and Legal & Social and Relational \\
\hline $\begin{array}{l}\text { Manufacturer- } \\
\text { dealer }\end{array}$ & $\begin{array}{l}\text { Manufacturer relies on } \\
\text { dealers to sell products }\end{array}$ & $\begin{array}{l}\text { Both actors generate revenue } \\
\text { streams based on product sales } \\
\text { Both actors generate revenue } \\
\text { streams based on spare parts }\end{array}$ & $\begin{array}{l}\text { Manufacturer trains and } \\
\text { supports dealer regarding } \\
\text { products and product features } \\
\text { Manufacturer has marketing } \\
\text { and sales resources that } \\
\text { interact with dealers }\end{array}$ \\
\hline Dealer-user & $\begin{array}{l}\text { User relies on dealer to } \\
\text { provide maintenance and } \\
\text { repair sold products }\end{array}$ & $\begin{array}{l}\text { Dealer receives direct payments } \\
\text { for products from users } \\
\text { Dealer receives direct payments } \\
\text { for service and maintenance } \\
\text { (incl. spare parts) from users }\end{array}$ & $\begin{array}{l}\text { User relies on dealer to be } \\
\text { knowledgeable about and } \\
\text { recommend products }\end{array}$ \\
\hline $\begin{array}{l}\text { Manufacturer- } \\
\text { user }\end{array}$ & None & $\begin{array}{l}\text { User warranty provided by } \\
\text { manufacturer }\end{array}$ & Nommunity \\
\hline
\end{tabular}


Table 4. Network ties in the transitive triad

\begin{tabular}{|c|c|c|c|}
\hline Tie & Structural and Technical & Economic and Legal & Social and Relational \\
\hline $\begin{array}{l}\text { Manufacturer- } \\
\text { dealer }\end{array}$ & $\begin{array}{l}\text { Manufacturer relies on } \\
\text { dealers to sell products } \\
\text { Manufacturer provides } \\
\text { infrastructure and ICT } \\
\text { system that dealer needs } \\
\text { for service }\end{array}$ & $\begin{array}{l}\text { Both actors generate } \\
\text { revenue streams based on } \\
\text { product sales } \\
\text { Both actors generate } \\
\text { revenue streams based on } \\
\text { spare parts } \\
\text { Both actors generate } \\
\text { revenue streams based on } \\
\text { service contracts }\end{array}$ & $\begin{array}{l}\text { Manufacturer trains and } \\
\text { supports dealer regarding } \\
\text { products and product features } \\
\text { Manufacturer trains and } \\
\text { supports dealer's business and } \\
\text { development } \\
\text { Manufacturer's marketing and } \\
\text { sales resources interact with } \\
\text { dealers' } \\
\text { Increased information } \\
\text { exchange and points of } \\
\text { interaction between actors }\end{array}$ \\
\hline Dealer & $\begin{array}{l}\text { User relies on dealer to } \\
\text { provide maintenance and } \\
\text { repair on sold products } \\
\text { Dealer installs and } \\
\text { administers system } \\
\text { hardware and software } \\
\text { needed by user } \\
\text { Both actors make co- } \\
\text { specialized investments in } \\
\text { technology and training }\end{array}$ & $\begin{array}{l}\text { Dealer receives direct } \\
\text { payments for products from } \\
\text { users } \\
\text { Dealer receives continuous } \\
\text { payments for service and } \\
\text { maintenance from users } \\
\text { User relies on dealer to } \\
\text { optimize machine fleet } \\
\text { Dealer and user agree on } \\
\text { terms of service contracts }\end{array}$ & $\begin{array}{l}\text { User relies on dealer to } \\
\text { recommend products and } \\
\text { develop business } \\
\text { Dealer has local presence in } \\
\text { user community } \\
\text { Dealer and user increase } \\
\text { interaction points }\end{array}$ \\
\hline $\begin{array}{l}\text { Manufacturer- } \\
\text { user }\end{array}$ & $\begin{array}{l}\text { Manufacturer provides } \\
\text { web portal needed by user } \\
\text { Manufacturer and user } \\
\text { interact through ICT } \\
\text { system }\end{array}$ & $\begin{array}{l}\text { User warranty provided by } \\
\text { manufacturer } \\
\text { Manufacturer generates } \\
\text { revenue through service- } \\
\text { related subscription fees } \\
\text { Manufacturer generates } \\
\text { revenue through service- } \\
\text { specific hardware sales }\end{array}$ & $\begin{array}{l}\text { Manufacturer exchanges } \\
\text { information directly with user } \\
\text { Manufacturer and user increase } \\
\text { interaction points } \\
\text { Manufacturer increases brand } \\
\text { awareness through direct link }\end{array}$ \\
\hline
\end{tabular}




\section{Appendix 1. Reciprocal value propositions in the marketing literature.}

\begin{tabular}{|c|c|}
\hline Authors & Concepts and definitions \\
\hline $\begin{array}{l}\text { Ballantyne } \\
(2003)\end{array}$ & $\begin{array}{l}\text { Value propositions are unilateral initiatives that mean different things in different places. For } \\
\text { internal marketing, a two-way value proposition might be communicated as an offer of mutual } \\
\text { value; transparent about to whom value flows; perceived as a fair exchange of value; co- } \\
\text { created through interactions of two or more parties; and continuing (or increasing) use value. } \\
\text { The emphasis is on mutual value, where mutual benefits are transparent to all parties and } \\
\text { promises are fulfilled; mutual trust, mutual commitment and mutual obligation are required. }\end{array}$ \\
\hline $\begin{array}{l}\text { Ballantyne } \\
\text { and Varey } \\
(2006)\end{array}$ & $\begin{array}{l}\text { "Value propositions are reciprocal promises of value, operating to and from suppliers and } \\
\text { customers seeking an equitable exchange. Thus, value propositions are always two-way, quid } \\
\text { pro quo." (pp. } 344-345 \text {, italics in original) }\end{array}$ \\
\hline $\begin{array}{l}\text { Flint and } \\
\text { Menzer } \\
(2006)\end{array}$ & $\begin{array}{l}\text { "... suppliers must understand goals and end states for desired functional, relational, and } \\
\text { service benefits and sacrifices, and various relevant use situations for each member of the } \\
\text { buying center-members who often change as contracts and use situations change. The } \\
\text { resources to gain this level of understanding are significant but are required for the } \\
\text { development of solid value propositions... Since supplier value involves similar categories of } \\
\text { benefits and sacrifices as customer value, there is quite a lot that customers should understand } \\
\text { about suppliers' desires as well. So both parties are exchanging value propositions, and those } \\
\text { propositions include co-production opportunities and knowledge as key benefits... Integrated } \\
\text { value chain partners can only exchange value propositions." (p. 143, italics in original) }\end{array}$ \\
\hline $\begin{array}{l}\text { Ballantyne et } \\
\text { al. (2011) }\end{array}$ & $\begin{array}{l}\text { Reciprocal value propositions are communication practices that bring exchange activities, } \\
\text { relationship development, and knowledge renewal closer together. They can be initiated by } \\
\text { any party and initiate resource integration across a network of firm stakeholders. "Value } \\
\text { propositions should be crafted: as a reciprocal exchange of value; described in terms of } \\
\text { perceived benefits or reduced costs; transparent about to whom that value should flow and } \\
\text { how; perceived as a fair exchange of value; delivered over a time frame longer than a single } \\
\text { transaction; often co-created through interaction between two or more parties; and, congruent } \\
\text { with the relationship objectives set for a particular market." (p. 206) }\end{array}$ \\
\hline $\begin{array}{l}\text { Frow and } \\
\text { Payne (2011) }\end{array}$ & $\begin{array}{l}\text { Value propositions act as a systems- and stakeholder-unifying process, and as a value } \\
\text { alignment mechanism in a marketing system. }\end{array}$ \\
\hline $\begin{array}{l}\text { Kowalkowski } \\
(2011)\end{array}$ & $\begin{array}{l}\text { Both providers and customers can initiate reciprocal value propositions. Actors need to ensure } \\
\text { proper alignment between their value propositions and the operating resources available to } \\
\text { them; the subjective value perceptions of all potentially involved individuals are not } \\
\text { necessarily congruent among them; the nature of customer-provider interactions influences } \\
\text { value-creation potential and value-proposition emphasis; the benefits and risks for both actors } \\
\text { must be kept in mind when crafting a value proposition. The strategic management of the } \\
\text { value focus of each firm's value propositions should be understood as a dynamic, competently } \\
\text { developed operating resource that is at the heart of competitive advantage and performance. }\end{array}$ \\
\hline $\begin{array}{l}\text { Lusch and } \\
\text { Webster } \\
(2011)\end{array}$ & $\begin{array}{l}\text { Intention and capability to offer value of a particular kind in a particular way is communicated } \\
\text { to potential buyers and resource-provider partners by a value proposition. It is a marketing } \\
\text { responsibility to ensure that the firm's value proposition is communicated to, and understood } \\
\text { by, the entire network of resource-providing stakeholders. }\end{array}$ \\
\hline $\begin{array}{l}\text { Storbacka and } \\
\text { Nenonen } \\
(2011)\end{array}$ & $\begin{array}{l}\text { "Market propositions are in essence resource-integration promises: the focal actor promises to } \\
\text { enhance value creation for participating actors by creating a market configuration that makes } \\
\text { increased density of resources and capabilities and value co-creation possible. These } \\
\text { propositions should not be created only around products, but primarily focus on the needs of } \\
\text { different market actors and the opportunities for the focal actor to create solutions for these } \\
\text { needs." (p. 264) }\end{array}$ \\
\hline $\begin{array}{l}\text { Kowalkowski } \\
\text { et al. (2012) }\end{array}$ & $\begin{array}{l}\text { Value propositions form through reciprocal exchanges of knowledge among constellations of } \\
\text { resource-integrating actors whose knowledge is situated in their respective, idiosyncratic } \\
\text { practice. A co-creative practice of forming a value proposition consists of two principal }\end{array}$ \\
\hline
\end{tabular}




\begin{tabular}{|c|c|}
\hline & $\begin{array}{l}\text { elements: the script (understandings, procedures, and engagements) that each actor draws on } \\
\text { when engaging in the practice, and the activities (application, assessment, adaptation, and } \\
\text { adoption) of reciprocal exchange of knowledge between these actors. Firms thus should be } \\
\text { understood as multiple resource-integrating actors. }\end{array}$ \\
\hline $\begin{array}{l}\text { Truong et al. } \\
(2012)\end{array}$ & $\begin{array}{l}\text { Specific activities and resource integrations pertain to reciprocal value propositions in } \\
\text { practice. Reciprocal value proposition development enables interaction platforms to create } \\
\text { stability within network relationships. Constraints to reciprocal value propositions in } \\
\text { practice—dialogue and knowledge brokerage—-may also take on an enabling role. }\end{array}$ \\
\hline $\begin{array}{l}\text { Frow et al. } \\
\text { (2014) }\end{array}$ & $\begin{array}{l}\text { A value proposition is "a dynamic and adjusting mechanism for negotiating how resources are } \\
\text { shared within a service ecosystem" (p. 340). Value propositions are co-created, reciprocal } \\
\text { mechanisms through which actors offer and attract resources; value propositions in ecosystems } \\
\text { arise from the value potential inherent in actors' resources; value propositions influence the } \\
\text { composition of networks, determining with whom actors choose to engage and shaping the } \\
\text { nature of market interactions; value propositions may change over time and shape new } \\
\text { resource integration within the service ecosystem; value propositions act as a } \\
\text { balancing/alignment mechanism in the service ecosystem (pp. 344-345). }\end{array}$ \\
\hline $\begin{array}{l}\text { Payne and } \\
\text { Frow (2014a) }\end{array}$ & $\begin{array}{l}\text { "A value proposition is an organisation's offering to customers, representing a promise of } \\
\text { benefits of value that customers will receive during and after the usage experience. It identifies } \\
\text { both product and experiential benefits and costs (or sacrifices) that result from the relationship } \\
\text { between customer and organisation. A superior value proposition represents an offering to } \\
\text { customers that adds more value or solves a problem better than other similar competitive } \\
\text { offerings." (p. 240) }\end{array}$ \\
\hline $\begin{array}{l}\text { Siltaloppi and } \\
\text { Vargo (2014) }\end{array}$ & $\begin{array}{l}\text { "Value propositions are constituents of value co-creation and are 'the social glue that defines } \\
\text { service systems and their interactions in the context of larger ecosystems"' (p. 1282). "Value } \\
\text { propositions capture not only 'utilitarian' understandings of immediate 'outputs' of resource } \\
\text { integration, but (and more importantly) also allow us to understand the 'alignment' or shared } \\
\text { meaning between actors that influences value co-creating behaviors more broadly in the } \\
\text { system." (pp. 1282-1283) }\end{array}$ \\
\hline $\begin{array}{l}\text { Skålén et al. } \\
\text { (2014) }\end{array}$ & $\begin{array}{l}\text { Value propositions are promises of value creation that build on configurations of resources and } \\
\text { practices. Practices are grouped into three aggregates: representational, provision, and } \\
\text { management and organizational practices. }\end{array}$ \\
\hline $\begin{array}{l}\text { Chandler and } \\
\text { Lusch (2015) }\end{array}$ & Value propositions are "invitations from actors to one another to engage in service." (p. 1) \\
\hline $\begin{array}{l}\text { Vargo et al. } \\
(2015)\end{array}$ & $\begin{array}{l}\text { Value propositions are both the co-created outcomes and a medium of systemic human action. } \\
\text { "[V]alue-proposing actors, based on their institutional arrangements and their competences } \\
\text { (i.e., operant resources), engage in institutional work by recombining or proposing not only } \\
\text { new integrative practices, but also new normative and representational practices." (p. 69) }\end{array}$ \\
\hline
\end{tabular}




\section{Biographies}

Christian Kowalkowski is Associate Professor of Industrial Marketing at Linköping University, Sweden, and Assistant Professor of Marketing in the Centre for Relationship Marketing and Service Management at Hanken School of Economics, Finland. His current research activities concern service infusion, relationship dynamics, service innovation, and solutions marketing. He serves as Associate Editor of Journal of Service Management and Journal of Services Marketing and has published articles in journals such as European Journal of Marketing, Industrial Marketing Management, Journal of Business Research, and Journal of Service Management.

Daniel Kindström is Associate Professor of Industrial Marketing at Linköping University in Sweden. He is currently conducting research on service infusion, proactive market strategies and dynamic business models. His research appears in journals such as Industrial Marketing Management, Journal of Business Research, European Management Journal, and Journal of Service Management as well as in several books and book chapters.

Per Carlborg is a researcher and lecturer of Industrial Marketing at Linköping University, Sweden. His current research activities concern service innovation and relations in business networks. His research appears in journals such as Journal of Business \& Industrial Marketing, Journal of Service Theory and Practice, and Service Industries Journal. 